\title{
Interspecific combat in anurans: a case of Hypsiboas faber (Wied-Neuwied, 1821) (Hylidae) and Rhinella pombali (Baldissera-Jr, Caramaschi \& Haddad, 2004) (Bufonidae)
}

\author{
Mário Ribeiro de Moura* \\ Emanuel Teixeira da Silva \\ Sarah Mângia \\ Universidade Federal de Viçosa, Departamento de Biologia Animal, \\ Museu de Zoologia João Moojen, Vila Gianetti 32, CEP 36570-000, Viçosa-MG, Brazil \\ *Author for correspondence \\ mariormoura@gmail.com
}

Submetido em 12/04/2010

Aceito para publicação em 20/08/2010

\section{Resumo}

Combate interespecífico em anuros: um caso entre Hypsiboas faber (Wied-Neuwied, 1821) (Hylidae) e Rhinella pombali (Baldissera-Jr, Caramaschi \& Haddad, 2004) (Bufonidae). Nós reportamos um combate interespecífico envolvendo a perereca Hypsiboas faber e o sapo Rhinella pombali no sudeste do Brasil. Uma vez que a observação ocorreu após o início da interação, ambas as espécies podem ter iniciado a luta. Em geral, combates intra-específicos são mais comuns em espécies nas quais o macho é tão grande quanto ou maior que a fêmea, como observado em Hypsiboas faber. Dessa forma, o macho da perereca pode ter confundido o sapo com um oponente coespecífico. Por outro lado, machos de bufonídeos podem empregar a busca ativa por fêmeas, às vezes amplexando outros machos. Assim, o sapo pode ter amplexado a perereca e iniciado a luta.

Unitermos: interações interespecíficas, luta, território

\section{Abstract}

We report an interspecific combat involving the tree frog Hypsiboas faber and the toad Rhinella pombali in southeastern Brazil. Since the observation occurred after the beginning of the interaction, either one of the species may have started the fight. In general, intra-specific combats are more common for species in which the male is as large, as or larger than, the female, as observed in Hypsiboas faber. Thus, the male tree frog might have confused the toad with a conspecific opponent. On the other hand, bufonid males can use active searching for females, sometimes clasping other males or objects. Therefore, the toad might have clasped the male tree frog and it was this that provoked the subsequent wrestling.

Key words: fight, interspecific interactions, territory 
In areas where several species of frogs breed simultaneously, interspecific interactions may occur, varying from shifts in acoustic signals to aggressive encounters (Schwartz and Wells, 1984). However, the occurrence of interspecific combats in anurans has been rarely reported, being more common among closely related species (Schwartz and Wells, 1984). In general, aggressive interactions among heterospecific males occur by the use of aggressive calls in the defense of calling sites (Wells, 2007).

During an anuran survey on September $9^{\text {th }} 2009$ at around 19:30, we witnessed an interspecific combat between the tree frog Hypsiboas faber and the toad Rhinella pombali (Figure 1). The observation took place in a small temporary pond in the municipality of Viçosa, state of Minas Gerais, southeastern Brazil (2048'01.4”S, $42^{\circ} 51$ '45.6”'W, elev. 711m). An adult male of $H$. faber was observed holding the body of an adult male of $R$. pombali, on the water surface near the edge of the pond. The male of $H$. faber remained clinging to its opponent, fighting at all times, while the bufonid struck with its forelimbs, also rolling the $H$. faber throughout the fight, apparently trying to keep the tree frog underwater. After about one minute, the opponents separated, distancing themeselves about one meter away from each other. We did not hear any acoustic signals being emitted during the combat.

The abundance of the resource is expected to modify the intensity of the competition among individuals (Wells, 1977; Duellman and Trueb, 1986). In anurans, such resources are almost always oviposition sites or calling sites, which are disputed mainly by males (Wells, 2007). Territorial defense of oviposition sites is particularly common in males of $H$. faber who frequently defend nests and the area around them, which represents simultaneously a calling, a courtship, and an oviposition site (Martins and Haddad, 1988). As a result, the wrestling in $H$. faber is more frequent in high density choruses, varying from a few seconds to more than 10 minutes (Martins et al., 1998). Another feature that can stimulate competition is the availability of females (Wells, 2007). Males of several Brazilian bufonids engage in active searching during situations of very dense choruses, sometimes clasping other males or objects (Pombal-Jr. and Haddad, 2007). On the same night and at the same pond where we observed the reported event, at least another ten males of $H$. faber were calling together with a similar or superior number of males of $R$. pombali. Since the observation was made after the beginning of the combat, it is difficult to know which individual started the wrestling, both being possible scenarios.

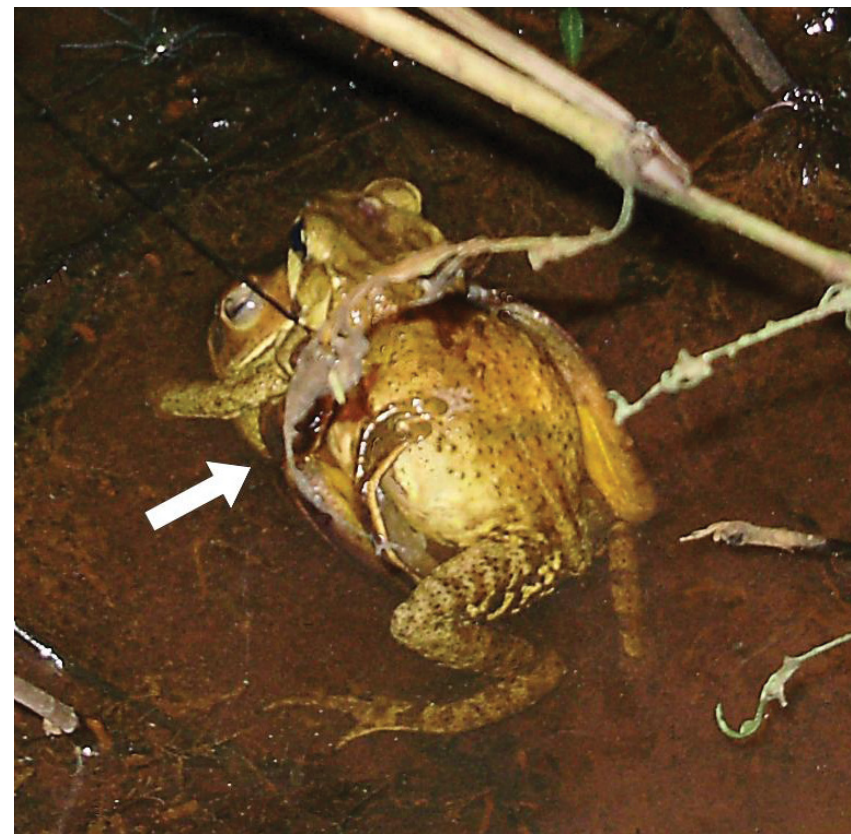

FIGURE 1: Adult males of Hypsiboas faber and Rhinella pombali wrestling in pond shallows (Viçosa, Minas Gerais, Brazil). Note the forelimbs of the $H$. faber clinging (white arrow) to the body of the R. pombali. Photo: M. R. Moura.

Evidence for $H$. faber as the starter of the combat is provided by the several territorial and aggressive behaviors described for this species (Lutz, 1960; 1973), including an escalated aggressive behavior among males, which can vary from territorial calls to physical fights (Martins et al., 1998). Since the available area for nest building was limited, the high number of males calling on that night might have influenced the beginning of the interspecific battle. In the case reported here, the male of $R$. pombali might have entered the territory of the male $H$. faber, and the latter could have confused the toad with another co-specific calling male, jumping toward the $R$. pombali and then beginning the combat. The male of $R$. pombali almost certainly moved in response to aggression as a defensive tactic, whereas the opponent was still clinging to its body. On the other 
hand, the possibility of $R$. pombali starting the combat cannot be rejected. Although the behavior of active search has not yet been reported for $R$. pombali, it is known for closely related species, such as $R$. ornata and $R$. henseli (Pombal-Jr. and Haddad, 2007). Thus, in the situation reported here, the male $R$. pombali could have confused the $H$. faber male with a co-specific female while searching for a mate, and attempted to amplex the latter by wrestling.

In the anuran species that present male combat, the males are as large as, or larger than, females in almost half of these combative forms, while in non-combative species the males are rarely as large as the females (Shine, 1979). This aspect of sexual dimorphism is observed in H. faber, a species in which males are as large as females (Martins, 1993) and is not verified in most Rhinella species, in which females are larger than males (e.g. Caramaschi and Niemeyer, 2003; BaldisseraJúnior et al., 2004; Brandão et al., 2007; Chaparro et al., 2007; Fouquet et al., 2007; Lehr et al., 2007; Maciel, 2008; Narvaes and Trefaut, 2009). Although reports of aggressive behavior for the Rhinella species has been only rarely reported (e.g. Haddad et al., 2008), we have already observed males of $R$. pombali exhibiting territorial behaviors, such as territorial call and attempts to move a neighboring male, indicating that these interactions may not be uncommon for these toads. The occurrence of territorial behavior in males of $R$. pombali is another piece of evidence for the toad as the starter of the combat described here, although it was not observed in this reported event.

\section{Acknowledgements}

We thank Marcelo Nogueira de Carvalho Kokubum, Sebastian Steinfartz and two anonymous referees for their comments on a previous draft of the manuscript. We are also obliged to Ana Paula Motta for helping during fieldwork, and the Universidade Federal de Viçosa for logistic support.

\section{References}

Baldiserra-Júnior, F. A.; Caramaschi, U.; Haddad, C. F. B. 2004. Review of the Bufo crucifer species group, with descriptions of two new related species (Amphibia, Anura, Bufonidae). Arquivos do Museu Nacional, 62 (3): 255-282.

Brandão, R. A.; Maciel, N. M.; Sebben, A. 2007. A new species of Chaunus from Central Brazil (Anura; Bufonidae). Journal of Herpetology, 41 (2): 309-316.

Duellman, W. E.; Trueb, L. 1986. Biology of amphibians. McGrawHill, New York, USA, 670pp.

Caramaschi, C.; Niemeyer, H. 2003. Nova espécie do complexo de Bufo margaritifer (Laurenti, 1768) do Estado do Mato Grosso do Sul, Brasil (Amphibia, Anura, Bufonidae). Boletim do Museu Nacional, 501: 1-16.

Chaparro, J. C.; Pramuk, J. B.; Gluesenkamp A. G. 2007. A new species of arboreal Rhinella (Anura: Bufonidae) from cloud forest of southeastern Peru. Herpetologica, 63: 203-212.

Fouquet, A.; Gaucher, P.; Blanc, M.; Velez-Rodrigues, C. M. 2007. Description of two new species of Rhinella (Anura: Bufonidae) from the lowlands of the Guiana shield. Zootaxa, 1663: 17-32.

Haddad, C. F. B.; Toledo L. F.; Prado, C. P. A. 2008. Atlantic Forest amphibians. Editora Neotropica, São Paulo, Brazil, 243pp.

Lehr, E.; Pramuk, J.; Hedges, B.; Córdova, J. H. 2007. A new species of arboreal Rhinella (Anura: Bufonidae) from YanachagaChemillén National Park in central Peru. Zootaxa, 1663: 1-14.

Lutz, B. 1960. Noção de território em anfíbios anuros Hyla faber Wied. Anais da Academia Brasileira de Ciências, 32: 143-145.

Lutz, B. 1973. Brazilian species of Hyla. University of Texas Press, Austin, USA, 272pp.

Maciel, N. M. 2008. Sistemática e biogeografia do grupo Rhinella marina (Linnaeus, 1758) (Anura: Bufonidae). $\mathrm{PhD}$ Thesis, Universidade de Brasília, Brazil, 128pp.

Martins, M. 1993. Observations on the reproductive behaviour of the smith frog, Hyla faber. Herpetological Journal, 3: 31-34.

Martins, M.; Haddad, C. F. B. 1988. Vocalizations and reproductive behaviour in the smith frog, Hyla faber Wied (Amphibia: Hylidae). Amphibia-Reptilia, 9: 49-60.

Martins, M.; Pombal-Jr, J. P.; Haddad, C. F. B. 1998. Escalated agressive behaviour and facultative parental care in the nest building gladiator frog, Hyla faber. Amphibia-Reptilia, 19: 65-73.

Narvaes, P.; Rodrigues, M. T. 2009. Taxonomic revision of Rhinella granulosa species group (Amphibia, Anura, Bufonidae), with a description of a new species. Arquivos de Zoologia, 40 (1): 1-73.

Pombal-Jr., J. P.; Haddad, C. F. B. 2007. Estratégias reprodutivas em anuros. In: Nascimento, L. B. \& Oliveira, M. E. (Eds). Herpetologia no Brasil II. Sociedade Brasileira de Herpetologia, Belo Horizonte, Brazil, p.101-116.

Schwartz, J. J.; Wells, K. D. 1984. Interspecific acoustic interactions of the Neotropical treefrog Hyla ebracata. Behaviour Ecology and Sociobiology, 14 (3): 211-224.

Shine, R. 1979. Sexual selection and sexual dimorphism in the Amphibia. Copeia, 1979: 297-306.

Wells, K. D. 1977. The social behaviour of anuran amphibians. Animal Behaviour, 25: 666-693.

Wells, K. D. 2007. The ecology and behavior of amphibians. The University of Chicago Press, Chicago, USA, 1148pp. 